УАK 342.7

ББК 67.400 .3

DOI 10.22394/1682-2358-2020-1-64-72

R.V. Graf, post-graduate student of the Constitutional and International Law Department, Povolzhsky Institute of Management named after P.A. Stolypin, Branch of the Russian Presidential Academy of National Economy and Public Administration

\section{PLACE AND ROLE OF THE CONSTITUTIONAL RIGHT \\ TO COMPENSATION \\ BY THE STATE \\ IN THE SYSTEM \\ OF CONSTITUTIONAL RIGHTS AND FREEDOMS}

The place of the constitutional right to compensation by the State in the system of constitutional rights and freedoms is considered. It is concluded that this constitutional right belongs to a special group of rights for the protection of other rights and freedoms. It is also justified that it belongs to an absolute, individual, positive human right.

Key words and word-combinations: human rights, the constitutional right to compensation by the State, classification of the rights.
P.В. Граф, аспирант кафедрьг конституиионного и международного праља Поволжского института управления имени П.А. Стольтина филиала Российккой академии народного хозяйсmъа и государственной службь при Президенте РФ (email: graf@piuis.ru)

\section{МЕСТО И РОАЬ ПРАВА НА ВОЗМЕШЕНИЕ ГОСУААРСТВОМ ВРЕАА B CИСТЕMЕ КОНСТИТУЦИОННЫХ ПРАВ И СВОБОА}

\footnotetext{
Аннотация. Рассматривается место конституционного права на возмещение государством вреда в системе конституционных прав и свобод. Делается вывод, что данное конституционное право относится к особой группе прав по защите иных прав и свобод. Обосновывается его принадлежность к абсолютным, индивидуальным, позитивным правам человека.

Ключевые слова и словосочетания: права человека, конституционное право на возмещение государством вреда, классификация прав.

$\Pi$ раво на возмещение государством вреда, являясь субъективным конституционным правом, занимает определенное место в системе Аругих конституционных прав и свобод. В российской правовой науке существуют разиичные классификации прав человека. K примеру, А.И. Ауковская насчитывает более Аесяти критериев их кмассификации. Некоторые из них от-
} 
ражают офиџиальные, то есть закрепленные законодательно, разграничения прав, Аругие - исключительно доктринальные [1, с. 15]. Но в Аюбом случае такое разнообразие является вполне допустимым и даже целесообразным. Как отмечал в связи с этим известный отечественный конституџионалист $\Lambda . А$. Воеводин, «кмассификаций прав и обязанностей домжно быть много, та как даже весьма совершенная классификация прав и обязанностей не исключает, а предполагает другие виды классификаџии, и отсюда было бы ошибкой настаивать на универсальном характере той или иной кмассификации прав или прав и обязанностей и отвергать Аругие виды» [2, с. 238].

На наш взгляА, прежде всего имеет смысл обратиться к классификаџиям, непосредственно вытекающим из текста Конституции РФ. ЗАесь в первую очередь следует отметить, что в конституџионно-правовой науке права и свободы человека и гражданина подразделяются на права, прямо сформулированные в Конститущии РФ, и права, вытекающие из ее норм. Конститущионное право на возмешение государством вреда приведено в тексте российской конституции, соответственно, оно относится к первой группе.

Обращаясь к правам, перечисленным в тексте Конституции РФ, обратим внимание, что глава 2 Основного Закона именуется «Права и свободы человека и гражданина». Из этого могично следует, что все признаваемые и гарантируемые в Российской Федерации права подразделяются на права человека и права гражданина. Аанное разделение прав кичности, впервые закрепленное во французской Аеклараџии прав человека и гражданина, обусловлено дуализ-

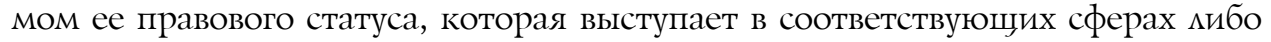
как человек, Аибо как гражданин: цичность выступает как человек в сфере экономической (гражданское общество) и как гражданин - в сфере политической (политическая общность) [3] .

В настоящее время, несмотря на то что в международно-правовых актах дефиниџии «права человека», «права гражданина», «права мичности», как правило, имеют одно и то же значение [4, с. 8], в отечественной конституционно-правовой науке они чаще разграничиваются. При этом в юриАической китературе проблема соотношения прав человека и прав гражданина решалась неоднозначно, причем расхождения порой были весьма значительны [5]. Так, ряд специалистов, справедливо указывая, что права человека по сути общесоџиальная категория, представцяют собой социальные возможности и необходимости, приходят к выводу, что права человека - это права, которые существуют еще до государственного их признания; в то время как права гражданина - это такие права человека, которые находятся поА охраной и защитой государства [6]. Исходя из этой позиџии, конститущионное право на возмешение государством вреда относится именно к правам гражданина, поскольку оно полностью и непосредственно зависит от его признания и гарантирования государством.

ОАнако имеется и Аругое мнение, в рамках которого разграничение межАу правами человека и правами гражданина производится исключительно по субъектному составу правообцадателей. Соответственно, под правами человека понимаются права и свободы, присущие всем июдям независимо от 
гражданства, вытекающие из естественного права, принадлежащие мюбому человеку в мюбое время в силу факта его рождения, принадлежности к биологическим созданиям, считающимся мюдьми. Эти права неотчуждаемы [7, с. 163]. Права же гражданина принадлежат только тем цицам, которые состоят в гражданстве Аанного государства. В демократических государствах большая часть конституционных прав - это права человека. Правами гражАанина являются в основном политические права и отдельные права Аругих видов [8, с. 18].

Конституция РФ, закрепцяя во второй главе права человека и гражданина, четко называет их обладателей - субъектов: «гражАане Российской Федерации» (ст. 3-33, 36 и Ар.) мибо «кажАый» (ст. 20-23, 26-30 и Ар.). Вполне очевидно, что во втором случае речь идет как о гражданах Российской Федерации, так и об иных миџах, не являющихся таковыми. Соответственно, здесь в основу отделения прав человека от прав гражданина положкен второй критерий.

В ст. 53 Конститущии РФ, закрепляющей конституционное право на возмещение государством вреда, используется применительно к данному праву категория «кажАый», то есть правом на возмещение вреда могут воспользоваться как граждане Российской Федерации, так и иностранцы и мица без гражданства. Соответственно, рассматриваемое право следует отнести к правам человека.

Исходя из субъектного состава в научной митературе выделяется классификация прав и свобод человека и гражданина по субъекту осуществления прав. По этому критерию принято разграничивать индивидуальные права и комлективные (солидаристские) права, обладание и пользование которыми могут быть только комлективными. С этой позиџии конституционное право на возмещение государством вреда, хотя и может в определенных случаях осушествляться группами $и ц$, явцяется все же инАивидуацьным правом.

Наконец, еще одна классификация прав, напрямую вытекающая из соАержания Конституции РФ, подраздемяет их на абсолютные и относительные. Абсолютными в науке конституционного права именуются права, не подиежащие ограничениям ни при каких обстоятельствах. В части Конституции РФ установцены так называемые абсолютные права и свободы, которые «не подлежат ограничению» - права и свободы, предусмотренные ст. 20, 21 , 23 (ч. 1), 24, 28, 34 (ч. 1), 40 (ч. 1), 46-54 [9; 10, с. 155-156]. Поскольку в данном случае все определено непосредственно конституционным текстом, можно констатировать, что конституционное право на возмещение государством вреда является абсолютным правом.

Следующая классификация прав и свобод человека и гражданина напрямую из текста Конституции РФ не вытекает. Тем не менее она явцяется, пожалуй, самой известной и наиболее часто используемой в научной и учебной митературе. Речь идет о разделении прав и свобод человека и гражданина в зависимости от сфер их реализаџии. Правовой основой ее выступают принятые в 1966 г. Генеральной Ассамблеей ООН два международных пакта - 
о гражданских и политических правах [11] и об экономических, соџиальных и культурных правах [12]. Вполне могично, что по данному критерию права и свободы, как правило, подразделяются на пять групп: мичные (гражданские), политические, экономические, социальные и культурные права [13; 14, с. 154-157]. Кроме того, ряд специалистов выдемяет также и отдельную группу экологических прав $[15 ; 16$, с. $75 ; 17]$.

Как представляется, конституционное право на возмещение государством вреда вполне очевидно не явмяется культурным или экологическим. Никак нельзя отнести его и к политическим, поскольку они «описывают правомочия, позвомяющие гражданам участвовать в формировании и осуществлении государственной власти» [13]. Реализуя конститущионное право на возмещение государством вреда, гражданин, безусловно, взаимодействует с органами государственной власти, однако считать его действия формированием и (или) осуществцением государственной власти достаточно сложно (во всяком случае, напрямую).

Конститущионное право на возмещение государством вреда имеет опреАеленные точки пересечения с экономическими правами в том смысле, что, как правияо, связано с реализацией имущественных отношений (возмещение государством вреда осуществляется чаще всего путем выплат гражданам, пострадавших от незаконных действий органов государственной власти и их должностных миц). ОАнако возмешение может осуществцяться и иными способами, например, применительно к жертвам политических репрессий путем восстановления их в гражданстве, возврате государственных награА и т.п.; если речь идет о реабилитации репрессированных народов, здесь используются такие меры, как восстановцение территориальной цемостности, существовавшей до антиконституционной политики насильственного перекраивания границ, на восстановление национально-государственных образований, сложившихся до их упразднения, возврашение в места традиционного проживания и Аругие.

Экономические права граждан «возникают в результате осуществления гражданами экономической деятельности, а также в связи с полномочиями органов государственной власти и местного самоуправления, направленными на защиту и реализацию указанных прав, а также на контроль за их осуществмением» [18, с. 3]. Рассматриваемое конституџионное право на возмешение государством вреда не касается собственно экономической деятельности и, хотя и направлено на защиту нарушенных прав, но не в данной сфере.

Аостаточно сложным представляется разграничение конституционного права на возмещение государством вреда с соџиальными правами. Как отмечает К.Б. Бароџкая, «соџиальные права имеют совершенно иную природу и иные механизмы защиты, чем гражданские и политические. Аля реализации социальных прав недостаточно просто воздерживаться от вмешательства в данную сферу: их реализация предполагает активную роль государства в обеспечении гражданам достойного уровня жкизни и ряда иных благ» [19]. Изможкенное в определенной степени характеризует и конститущионное право на возмещение государством вреда. 
Более того, по мнению Г.А. Трофимовой, «сущность соџиальных прав состоит во взаимодействии, с одной стороны, индивида, в частности гражАанина конкретного государства, с Аругой стороны, сообщества граждан как большой общей семьи, где должна в силу морально-нравственных устоев проявцяться: забота о нуждающихся в помощи; поощрение тех, кто созАал что-то на общее благо; компенсачия потерь тем, чьи права бъли ущемлень в результате неправомерньхх действий представителей государственного аппарата (при невозможности компенсаџии непосредственно со стороны этих киџ); а также правомерных действий таких миџ, повлекших за собой причинение вреАа, так называемого риска управления» (курсив наш. - Р.Г.) [20, с. 8]. Таким образом, Г.А. Трофимова конституционное право на возмещение государством вреда относит именно к соџиальным правам.

ОАнако в полной мере с приведенной точкой зрения согласиться сложно. «Понятие "социальный” означает связь человека с обществом и затрагивает их взаимоотношения, подразумевает комплекс социальных благ, предоставмяемых чемовеку и гражданину государством, которое берет на себя ответственность за его жизнь в обществе» [21, с. 38]. Иными словами, соџиальные права в современном обществе имеют в первую очереАь гарантирующий характер, призванный обеспечить кищу определенный уровень образования, охраны здоровья, предоставления иных социальных благ и т.п.

Конституционное же право на возмешение государством вреда имеет характер преимушественно компенсаџионный, направленный на восстановление нарушенной в результате неправомерных действий органов государственной вмасти и государственных домжностных миџ ситуаџии, или на получение имущественной компенсаџии в случаях, когда такое восстановление в полном объеме невозможкно. Правда, и некоторые социальные права - а именно права на соџиальное обеспечение - имеют характер компенсаџии, однако основания этой компенсаџии разАичны: «...суть социального обеспечения - это компенсаџия дохода, недополученного по уважительным причинам» [22, с. 99] - материнство, инвацидность, достижение определенного возраста и т.п., в то время как применительно к конститущионному праву на возмешение государством вреда нельзя говорить о компенсации недополученного дохода как об основной цели рассматриваемого права.

Проводя границу межАу конституционным правом на возмещение госуАарством вреда и соџиальными правами, отметим, что оно несводимо только к имущественным благам или их эквивалентам, что характерно для соџиальных прав. Наконец, конституционное право на возмешение государством вреда в сиху прямого указания ч. 3 ст. 56 Конституции РФ не может быть ограничено. Это нельзя утверждать о соџиальных правах, наполнение которых напрямую зависит от экономической ситуаџии в государстве. «Их происхождение, состав и объем не просто допускают их сокращение вплоть до “ничего”, но и понуждают себя сократить, когда исполнение их невозможно или неџелесообразно, когда это будет решено в правомерной законодательной, бюАжетной, Аоговорной ими в административной проџедуре» [23, с. 71]. 
Таким образом, убедившись, что конституционное право на возмещение государством вреда не может быть отнесено к политическим, экономическим, социальным, экологическим и культурным правам, целесообразно рассмотреть его соотношение с правами кичными.

ЗАесь прежде всего необходимо отметить, что конституџионное право на возмещение государством вреда отсутствует в пактах о правах 1966 г. В то же время МежАународный пакт о гражАанских и политических правах упоминает о некоторых правах, которые могут рассматриваться как его составляющие. Так, в ч. 5 ст. 9 данного Пакта определяется, что «каждый, кто был жертвой незаконного ареста или содержания под стражей, имеет право на компенсацию, обладающую исковой симой». Часть 6 ст. 14 гласит: «Если какое-либо миџо окончательным решением было осуждено за уголовное преступление и если вынесенный ему приговор был впоследствии отменен или ему было даровано помилование на том основании, что какое-либо новое или вновь обнаруженное обстоятельство неоспоримо доказывает наличие судебной ошибки, то это миџо, понесшее наказание в результате такого осуждения, получает компенсаџию согласно закону, если не будет доказано, что указанное неизвестное обстоятельство не было в свое время обнаружено искмючительно или отчасти по его вине». Поскольку данные права очевидно не являются политическими, следовательно, авторы Пакта рассматривали их как гражданские (цичные). Это, безусловно, явмяется доводом (хотя и формальным) для отнесения конститущионного права на возмещение госуАарством вреда к кичным правам.

Каковы же признаки мичных прав? С.М. Шахрай подчеркивает, что мичные права и свободы являются неотчуждаемыми, присушими каждому от рождения, не зависящими от наличия или отсутствия гражданства [13]. Безусловно, все эти признаки характеризуют и конституционное право на возмещение государством вреда: оно принадлежит как гражданам Российской Федераџии, так и миџам, не имеющим такого гражданства; в силу ч. 3 ст. 56 Конституџии РФ явмяется неотчужАаемым; возникает у мюдей от рождения, а

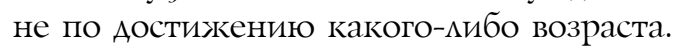

В то же время в митературе выдемяются и другие признаки мичных прав. Так, в комментарии к Федеральному закону «О правовом положении иностранных гражАан в Российской Федерации» применительно к кичным правам указывается:

1) эти права и свободы явцяются по своей сущности правами и свободами человека, то есть каждого, и не связаны напрямую с принадмежностью к гражданству государства;

2) эти права и свободы принадмежат каждому от рождения и неотчуждаемы, то есть их ограничение возможно только в цемях, установленных в ч. 1 ст. 55 Конститущии РФ, и только федеральным законом;

3) это естественные права, то есть их естественный характер обусловлен «природой» человека, без этих правовых возможностей теряет смысл само его существование, так как они служат необходимым условием дмя обеспечения естественных потребностей кичности [24]. 
Соответственно, возникает вопрос: применим ми к конституционному праву на возмещение государством вреда последний признак - является $\Lambda и$ данное право естественным? Аля ответа обратимся к еще одной кмассификации прав и свобод человека и гражданина - на естественные и позитивные.

Идея о естественных правах человека формировалась на протяжении двух с половиной тысячелетий как неотъемлемая часть теории естественного права, обосновывающей естественно-природный характер происхождения государства и права, взаимоотношений человека с государством. Каким же образом предлагается устанавливать границу между ними? Этот вопрос решается примерно смедующим образом:

1) естественные права - это правика поведения, вытекающие из свободной воли как естественного состояния человека и призванные служить мерилом и руководством Аля положительного законодательства, образцом его усовершенствования;

2) позитивные права - правима поведения, опредемяемые государством и облекаемые в определенную форму [25] .

По В.С. Соловьеву, «представители школы естественного права на особое место ставят ценности свободы и справедливости. Справедливость межит в основе самой доктрины естественного права. Ее содержание заключается в признании за Аругими права на жизнь и благополучие в той мере, в какой это признается каждым за самим собой... Естественное право в этом смысме очерчивает минимальную степень нравственного совершенства и тем самым ограничивает возможность безнравственного проявмения воли отдельных субъектов. Это позволяет посреАством права обеспечить внешний порядок, не Аопускающий каких бы то ни было проявлений зАа» [26, с. 148].

В таком понимании естественного права конституционное право на возмешение государством вреда вполне может пониматься как естественное. Аействительно, Аавая возможность цицу, пострадавшему от незаконных действий (бездействия) государства или его представителей, получить за это определенное возмещение, рассматриваемое право, с одной стороны, восстанавливает - насколько это возможно в данном случае - справедливость Амя самого потерпевшего от незаконных Аействий, с Аругой - уменьшает возможность совершения подобных противоправных действий в дальнейшем как в отношении миџа, получившего возмешение, так и в отношении третьих миџ и, тем самым, ограничивает возможность безнравственного проявления воли отдельных субъектов.

Подобное понимание естественных прав более характерно для теории права. Межау тем, как отмечал О.Е. Кутафин, «конџепџия естественного права в конституционно-правовой науке отличается от концепции естественного права в теории права. Прежде всего сама идея естественного права в конститущионно-правовой науке обладает более точным предметным характером, чем в теории права. Признание человека, его прав и свобод высшей ценностью оказывает непосредственное вцияние не только на соАержание основных прав и свобод человека и гражданина, но и на деятель- 
ность государства, на его компетенџию и потенциальные возможности» $[27$, c. 63] .

Конституционное право на возмещение государством вреда никак не вытекает из свободной воли как естественного состояния человека. Имея по своей природе гарантирующий характер, оно никак не свойственно индивиду имманентно, а определяется именно волей государства, только при наличии последней возможно создание механизмов, Аающих возможность его реацизации.

Таким образом, по нашему мнению, конститущионное право на возмещение государством вреда относится все же к позитивным, а не к естественным правам. Указанный вывод, разумеется, ставит поА вопрос и его отнесение к правам мичным. В связи с этим преАставцяется вполне обоснованной точка зрения С.А. Авакьяна, который, помимо гражданских (личных), политических, экономических, соџиальных, экологических и культурных прав, особо выдемяет "права по защите Аругих прав и свобод" $[28$, c. $669-670]$.

Аанная позиџия поддерживается и некоторыми Аругими авторами. В частности, В.Е. Гулиев и Ф.М. РуАинский выдемяют особую группу прав - общих юридических гарантий, которые обеспечивают реальность всех остальных прав и свобод [29, с. 143, 160-161]. К указанной категории они вполне обоснованно относят конститущионное право на судебную защиту прав и свобод (ч. 1 ст. 46); право на обращение в межкосударственные органы по защите прав и свобод человека (ч. 3 ст. 46); право на получение квалифицированной юридической помощи (ч. 1 ст. 48) и Аругие. Представцяется, что конституционное право на возмещение государством вреда, явцяясь по своей сути Аополнением к праву на защиту прав и свобод, также Аолжно быть отнесено к этой особой группе.

Подводя итог, можкно констатировать, что конституционное право на возмещение государством вреда, явмяясь субъективным правом человека и гражАанина, занимает определенное место в системе Аругих конституџионных прав и свобод. Анализ, проведенный в рамках настоящей публикации, позвомяет его классифицировать следующим образом: это право, сформулированное в Конституџии РФ, является абсолютным, индивидуальным, позитивным правом человека, относящимся к особой группе прав по защите Аругих прав и свобол.

\section{Библиографический список}

1. Луковская Д.И. Классификация прав и свобод человека и гражданина // История государства и права. 2007. № 15.

2. Воеводин Л.Д. Конституционные права и обязанности советских граждан. М., 1970.

3. Мишин А.А. Конституционное (государственное) право зарубежных стран: учебник для вузов. 17-е изд., испр. и доп. М., 2013.

4. Алексеева И.С., Валяровский Ф.И. Теоретические аспекты реализации прав, свобод и обязанностей человека и гражданина в Российской Федерации // Муниципальная служба: правовые вопросы. 2017. № 1. 
5. Шахрай С.М. Конституционное право Российской Федерации: учебник для академического бакалавриата и магистратуры. 4-е изд., изм. и доп. М., 2017.

6. Комментарий к Конституции Российской Федерации (постатейный) / под ред. В.Д. Зорькина. 2-е изд., пересмотр. М., 2011.

7. Маклаков В.В. Конституционное право зарубежных стран. Общая часть. М., 2006.

8. Преснякова A.B. Право на неприкосновенность частной жизни в системе конституционных прав и свобод человека и гражданина // Конституционное и муниципальное право. 2010. № 8 .

9. Шустров Д.Г. Иерархия конституционных ценностей // Конституционное и муниципальное право. 2013. № 6. С. 6-15.

10. Варламова Н. Классификация прав человека: подходы к проблеме // Сравнительное конституционное обозрение. 2009. № 4. С. 152-166.

11. Международный пакт о гражданских и политических правах (принят 16 дек. 1966 г. Резолюцией 2200 (XXI) на 1496-м пленарном заседании Генеральной Ассамблеи OOH). URL: https://www.un.org/ru/documents/decl_conv/conventions/pactpol.shtml

12. Международный пакт об экономических, социальных и культурных правах (принят 16 дек. 1966 г. Резолюцией 2200 (XXI) на 1496-м пленарном заседании Генеральной Ассамблеи ООН) [Электронный ресурс]. Доступ из МПС «КонсультантПлюс».

13. Шахрай C.M. Конституционное право Российской Федерации: учебник для академического бакалавриата и магистратуры. 4-е изд., изм. и доп. М., 2017.

14. Иванов Г.И. Права человека: учебное пособие / под ред. М.Ф. Чудакова. М., 2004.

15. Велиева Д.С. Система конституционных экологических прав и обязанностей в Российской Федерации / под ред. В.Т. Кабышева. М., 2009.

16. Велиева Д.С. Понятие конституционных экологических прав и их значение в системе действующего правового регулирования // Конституционное и муниципальное право. 2011. № 3.

17. Назарова И.С. Экологические права личности: конституционно-правовое преломление // Конституционное и муниципальное право. 2007. № 9.

18. Соловьев A.A. Экономические права граждан Российской Федерации: понятие и виды // Государственная власть и местное самоуправление. 2011. № 12.

19. Барочкая К.Б. Конституционное право на социальное обеспечение в системе прав человека и гражданина: дис. ... канд. юрид. наук. Челябинск, 2007.

20. Трофимова Г.А. Социальные права: критерии определения нуждающихся в помощи // Социальное и пенсионное право. 2016. № 3.

21. Соловьев A.A. К вопросу о разграничении экономических и социальных прав граждан как самостоятельных групп конституционных прав и их защита средствами прокурорского надзора // Конституционное и муниципальное право. 2019. № 1.

22. Ахмедиина А.Н. Право на материнский (семейный) капитал в системе мер социального обеспечения // Журнал российского права. 2009. № 1 (145).

23. Арановский К.В., Князев С.Д., Хохлов Е.Б. О правах человека и социальных правах // Сравнительное конституционное обозрение. 2012. № 4.

24. Жеребияов А.Н. [и др.]. Комментарий к Федеральному закону от 25 июля 2002 г. № 115-Ф3 «О правовом положении иностранных граждан в Российской Федерации (постатейный)» [Электронный ресурс]. Доступ из МПС «КонсультантПлюс».

25. Мелехин A.B. Теория государства и права: учебник. М., 2007.

26. Соловьев В.С. Оправдание добра. М., !994.

27. Кутафин О.Е. Предмет конституционного права. М., 2001.

28. Авакьян С.А. Конституционное право России: учебное пособие: в 2 т. 4-е изд., перераб. и доп. М., 2010. Т. 1.

29. Гулиев В.Е., Рудинский Ф.М. Демократия и достоинство личности. М., 1983. 